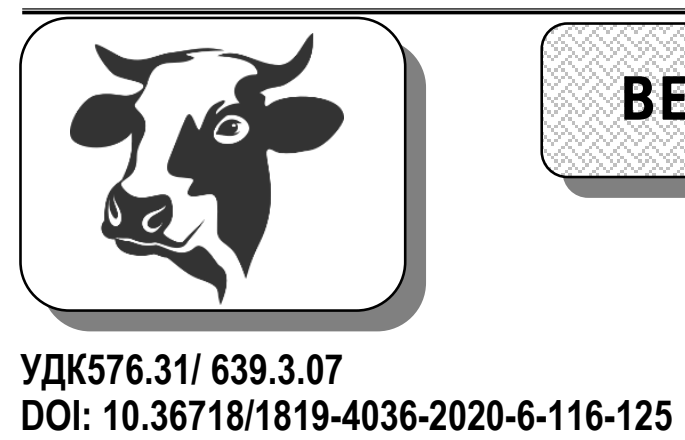

ВЕТЕРИНАРИЯ И ЗООТЕХНИЯ

А.А. Тыхеев, С.Д. Жамсаранова, С.Н. Лебедева, И.А. Кутырев, Е.А. Томитова, В.А. Петерфельд, Ю.С. Путункеева, М.В. Игнатьева

\title{
МОРФОЛОГИЧЕСКИЕ ИЗМЕНЕНИЯ СТРУКТУРЫ СЕЛЕЗЕНКИ НЕРЕСТОВОГО ОМУЛЯ, ЗАРАЖЕНHОГО D.DENDRITICUM
}

\author{
A.A. Tykheev, S.D. Zhamsaranova, S.N. Lebedeva, \\ I.A. Kutyrev, E.A. Tomitova, V.A. Peterfeld, \\ Yu.S. Putunkeeva, M.V. Ignatyeva
}

\section{MORPHOLOGICAL CHANGES IN THE SPLEEN STRUCTURE OF SPAWNING OMUL INFECTED WITH D. DENDRITICUM}

Тыхеев Анатолий Александрович - канд. ветеринар. наук, науч. сотр. Биотехнологического центра Восточно-Сибирского государственного университета технологий и управления, г. Улан-Удэ. E-mail: tykheev.a@mail.ru

Жамсаранова Сэсэгма Дашиевна - д-р биол. наук, проф., директор Биотехнологического центра Восточно-Сибирского государственного университета технологий и управления, г. Улан-Удэ. E-mail: zhamsarans@mail.ru

Лебедева Светлана Николаевна - д-р биол. наук, проф. каф. биотехнологии ВосточноСибирского государственного университета технологий и управления, г. Улан-Удэ.

E-mail: lebedeva1959@mail.ru

Томитова Елизавета Алексеевна - д-р. ветеринар. наук, проф. каф. ветеринарно-санитарной экспертизы, микробиологии и патоморфологии Бурятской государственной сельскохозяйственной академии им. В.Р. Филиппова.

E-mail: tomitova61@mail.ru

Кутырев Иван Александрович - д-р биол. наук, ст. науч. сотр. лаб. паразитологии и экологии гидробионтов Института общей и экспериментальной биологии СО РАН, г. Улан-Удэ.

E-mail: tykheev.a@mail.ru

Петерфельд Владимир Августович - канд. биол. наук, руководитель Байкальского филиала Всероссийского НИИ рыбного хозяйства и океанографии, г. Улан-Удэ. E-mail: bf-grc@yandex.ru
Tykheev Anatoly Alexandrovich - Cand. Veterinary Sci., Staff Scientist, Biotechnological Center, East Siberian State University of Technologies and Management, Ulan-Ude.

E-mail: tykheev.a@mail.ru

Zhamsaranova Sesegma Dashievna - Dr. Biol. Sci., Prof., Director, Biotechnological Center, East Siberian State University of Technologies and Management, Ulan-Ude.

E-mail: zhamsarans@mail.ru

Lebedeva Svetlana Nikolaevna - Dr. Biol. Sci., Prof., Chair of Biotechnology, East Siberian State University of Technologies and Management, UlanUde.

E-mail: lebedeva1959@mail.ru

Tomitova Elizaveta Alexeevna - Dr. Veterinary Sci., Prof., Chair of Veterinary and Sanitary Examination, Microbiology and Pathomorphology, Buryat State Agricultural Academy named after V.R. Filippov.

E-mail: tomitova61@mail.ru

Kutyrev Ivan Alexandrovich - Dr. Biol. Sci., Senior Staff Scientist, Lab. of Parasitology and Ecology of Hydrobionts, Institute of General and Experimental Biology SB RAS, Ulan-Ude.

E-mail: tykheev.a@mail.ru

Peterfeld Vladimir Avgustovich - Cand. Biol. Sci., Head, Baikal Branch, All-Russia Research Institute of Fishery and Oceanography, Ulan-Ude.

E-mail: bf-grc@yandex.ru 
Путункеева Юлия Сыреновна - студ. 4-го курса Восточно-Сибирского государственного университета технологий и управления, г. Улан-Удэ. E-mail: tykheev.a@mail.ru

Игнатьева Маргарита Викторовна - студ. 4-го курса Восточно-Сибирского государственного университета технологий и управления, г. Улан-Удэ. E-mail: tykheev.a@mail.ru

В работе изучались морфологические особенности структуры селезенки нерестового омуля, зараженного Diphyllobothrium dendriticum на стадии плероцеркоида, в зависимости от степени инвазии стенки пищеварительного тракта. Объектом исследования явились половозрелье особи омуля, добытые в местности Малое Колесово Кабанского района Республики Бурятия по квоте Байкальского филиала ФГБНУ ВНИРО (в рамках плана ресурсньх исследований на 2019 год). В ходе исследования выявлены морфометрические показатели внутренней структуры селезенки омуля, неинвазированного плероцеркоидами, и их изменения при разной степени инвазивности. Общее количество особей для анализа составило 17 голов, из них две особи здоровые, остальные с разной степенью заражения гельминтами. После взвешивания и измерения линейных размеров тела рыб произведено взятие крови из хвостовой артерии. Степень инвазии определялась путем подсчета плероцеркоидов на стенках кишечника. У незараженных особей омуля наблюдалась классическая морфологическая картина селезенки, при микроскопии в белой и красной пульпе отмечалось значительное содержание гемосидерина. При низкой степени инвазии омуля отмечены структурные изменения тканей селезенки с уменьшением содержания гемосидерина, характеризующиеся расстройством микроциркуляции: просвет сосудов расширен, венозное кровенаполнение, стаз и мелкие очаговые кровоизлияния. Наблюдалась неравномерная бугристая капсула и расширение подкапсулярных трабекул. Ткани селезенки омуля с высокой степенью инвазии брюшной полости приобрели мозаичную структуру с признаками гиперплазии и хронического полнокровия. Наблюдали незначительные площади пульпы с угнетенными центрами размножения и с резко расширенньми центральными артериями, указывающими на изменения иммунного статуса.
Putunkeeva Yulia Syrenovna - 4-Year Student, East Siberian State University of Technologies and Management, Ulan-Ude. E-mail: tykheev.a@mail.ru

Ignatyeva Margarita Victorovna - 4-Year Student, East Siberian State University of Technologies and Management, Ulan-Ude.

E-mail: tykheev.a@mail.ru

Ключевые слова: Diphyllobothrium dendriticum, плероцеркоид, селезенка, омуль, капсула, трабекула, белаяпульпа, краснаяпульпа.

Morphological features of the structure of the spleen of spawning omul, infected with Diphyllobothriumdendriticum at plerocercoid stage, were studied, depending on the degree of invasion of the wall of the digestive tract. The object of the study was sexually mature omul specimens obtained in the Maloe Kolesovo area of Kaban district of the Republic of Buryatia according to the quota of the Baikal branch of the FSBRI ARSRIFO (as part of the resource research plan for 2019). During the study morphometric indicators of the internal structure of omul spleen, not invaded by plerocercoids and their changes with varying degrees of invasiveness were revealed. The total number of individuals for analysis was 17 heads, two of which were healthy, the rest were with different degrees of helminth infection. After weighing and measuring linear dimensions of the body of the fish, the blood was taken from the caudal artery. The degree of invasion was determined by counting plerocercoids on the intestinal walls. In uninfected omul specimens, classical morphological picture of the spleen was observed, with microscopy in white and red pulp, significant hemosiderin content was noted. With a low degree of omul invasion, structural changes in spleen tissues were noted with a decrease in hemosiderin content, characterized by the disorder of microcirculation: vascular lumen widened, venous blood filling, stasis and small focal hemorrhages. An uneven tuberous capsule and expansion of the subcapsular trabeculae were observed. Omul spleen tissues with a high degree of invasion of the abdominal cavity acquired a mosaic structure with the signs of hyperplasia and chronic plethora. Not large areas of pulp were observed with inhibited reproduction centers and sharply expanded central arteries, indicating changes in the immune status. 
Keywords: Diphyllobothrium dendriticum, plerocercoid, spleen, omul, capsule, trabecula, white pulp, red pulp.

Введение. За последние десять лет мировая аквакультура удвоила свою продукцию [1]. Однако параллельно отмечается увеличение случаев паразитоза среди рыб, наносящих серьезный урон рыбоводной промышленности [2-5]. Цестодозы в некоторых эндемичных регионах по своему значению выходят на первый план среди остальных гельминтозов. На территории России ежегодно дифиллоботриозом заболевает более 6 тысяч человек [6-10].

Наибольшее эпидемиологическое и эпизоотическое значение в Байкальском регионе имеет лентец чаечный D. dendriticum семейства Diphyllobothriidae (Luhe, 1910). В данной паразитарной системе омуль является облигатным дополнительным хозяином лентеца. На фазе плероцеркоида этот лентец паразитирует у лососевидных рыб - байкальского омуля, байкальского хариуса, байкальского сига и др.

В экологических исследованиях патоморфологические изменения внутренних органов рыб являются одним из объективных индикаторов негативного влияния среды, чему посвящено большое количество исследований. Данных по изучению микроморфологии органов иммунной системы рыб при инвазии гельминтами недостаточно. Иммунная система является одной из важнейших в организме рыб, фуннции которой наряду с нервно-эндокринной регуляцией направлены на сохранение гомеостаза [11-14]. Селезенка костистых рыб является многофуннкциональным органом (гемопоэтическим, лимфоцитопродуцирующим), и в связи с этим крайне важным является всестороннее изучение перифрерических органов иммунной системы как одного из звеньев механизма реагирования иммунной системы рыб в условиях присутствия в организме паразитических червей [15-17]. В то же время иммунный статус байкальского омуля - перспективного объекта промысла и эндемика озера Байкал - является малоизученным и представляет собой актуальное направление экологического мониторинга.

Цель исследования. Изучение морфологических особенностей селезенки нерестового омуля, зараженного D. dendriticum.
Задачи исследования: изучить гистологическую структуру селезенки байкальского омуля и выявить изменения морфометрических показателей внутренней структуры паренхимы селезенки при разной степени инвазии брюшной полости омуля плероцеркоидами.

Материал и методы. Объектом исследования явились половозрелые особи байкальского омуля, выловленные в условиях нерестовой миграции в протоке, впадающей в реку Селенга. Работы проводились по квоте Байкальского филиала ФГБНУ ВНИРО (в рамках плана ресурсных исследований на 2019 год) в местности Малое Колесово Кабанского района Республики Бурятия. Для исследования использовали живую рыбу, пойманную и помещенную в садок, в количестве 17 голов, среди которых оказались здоровыми неинвазированными - самец в возрасте 5 и самка в возрасте 6 лет (подсчет велся по годовым кольцам на чешуе). Мазки крови изготавливали на месте отбора, высушивали и фиксировали метанолом с последующим окрашиванием азур-эозином методом Романовского. Выловленные особи омуля были разделены на 3 группы: 1-я группа рыб - здоровые особи, норма; 2-я группа рыб - особи с низкой степенью инвазии, зараженность паразитами одного животного составила 2-3 гельминта; 3 группа омуля - высокая степень инвазии - от 18 и выше плероцеркоидов. После необходимых измерений материалы помещали в контейнер с нейтральным 10\% раствором формалина. Гистологический анализ проводили по общепринятой методике и после стандартной проводки заливали в парафин. Для морфометрии и сравнения состояния структуры селезенки было проанализировано по 10 срезов в каждой группе рыб. Гистологические срезы толщиной 5-6 мкм окрашивались гематоксилином и эозином по Эрлиху с последующим заключением в канадский бальзам.

Промеры структуры селезенки - толщину капсулы, ширину трабекул, диаметр и площадь белой пульпы проводили с использованием микроскопа Axiostarplus, видеокамеры для микроскопа MICROCAM по программе Micromedimages 1,0 при увеличении в 100, 200 и 400 раз. Полученные цифровые данные подвергали статистической обработке на персональном компьютере с помощью программы «MicromedExcel». 
Результаты исследования и их обсуждение. Селезенка, как известно, является основным лимфоцитопродуцирующим органом. Как следует из данных таблицы 1, в крови омуля, зараженного D. dendriticum, наблюдалось достоверное уменьшение $(p \leq 0,05)$ содержания общего белка, гемоглобина, меньшее число эритроцитов и лейкоцитов. Причем выраженность данных показателей зависела от уровня зараженности омуля. Сильнее всего снижение дан- ных показателей было отмечено у омуля с высокой степенью инвазии (3-я группа рыб). Результаты изучения видового состава лейкоцитов показали достоверное снижение $(p \leq 0,05)$ содержания лимфоцитов и увеличение сегментоядерных нейтрофилов у омуля с высокой степенью инвазии (3-я группа), а также эозинофилией у зараженных рыб (2-я, 3-я группы), что характерно для паразитарных инвазий и соответствующей степени инвазивности.

\section{Гематологические и биохимические показатели байкальского омуля $\left(\operatorname{Me}\left(Q_{1}-Q_{2}\right)\right)$}

\begin{tabular}{|c|c|c|c|}
\hline \multirow[t]{2}{*}{ Показатель } & $\begin{array}{c}\text { Незараженный } \\
\text { омуль }\end{array}$ & $\begin{array}{c}\text { Омуль с низкой } \\
\text { степенью инва- } \\
\text { зии } \\
\end{array}$ & $\begin{array}{l}\text { Омуль с высокой } \\
\text { степенью инвазии }\end{array}$ \\
\hline & 1-я группа & 2-я группа & 3-я группа \\
\hline Общий белок, г\% & $\begin{array}{c}10,4 \\
(10,2-10,6) \\
\end{array}$ & $\begin{array}{c}9,6^{* 1} \\
(9,3-9,9) \\
\end{array}$ & $\begin{array}{c}8,5^{* 1,2,3} \\
(8,2-8,8)\end{array}$ \\
\hline Гемоглобин, Г\% & $\begin{array}{c}11,2 \\
(10,7-11,8) \\
\end{array}$ & $\begin{array}{c}9,6^{* 1} \\
(9,4-9,9)\end{array}$ & $\begin{array}{c}8,9^{* 1,2} \\
(8,7-9,2)\end{array}$ \\
\hline Эритроциты, млн/мкл & $\begin{array}{c}1,3 \\
(1,2-1,4)\end{array}$ & $\begin{array}{c}1,05^{* 1} \\
(1,0-1,1)\end{array}$ & $\begin{array}{c}0,85^{* 1,2} \\
(0,8-0,9)\end{array}$ \\
\hline Лейкоциты, тыс/мкл & $\begin{array}{c}10,5 \\
(10,3-10,7) \\
\end{array}$ & $\begin{array}{c}8,3^{* 1} \\
(8,0-8,7)\end{array}$ & $\begin{array}{c}6,9^{* 1,2,3} \\
(6,5-7,3) \\
\end{array}$ \\
\hline Лимфоциты, \% & $\begin{array}{c}77,0 \\
(75,3-78,8)\end{array}$ & $\begin{array}{c}74,5 \\
(70,8-78,3)\end{array}$ & $\begin{array}{c}68,2^{* 1} \\
(66,9-69,1)\end{array}$ \\
\hline Моноциты, \% & $\begin{array}{c}4,2 \\
(3,8-4,6)\end{array}$ & $\begin{array}{c}5,2 \\
(4,6-5,7)\end{array}$ & $\begin{array}{c}5,8 \\
(4,7-6,9)\end{array}$ \\
\hline $\begin{array}{l}\text { Нейтрофилы } \\
\text { сегментоядерные, \% }\end{array}$ & $\begin{array}{c}10,0 \\
(8,8-11,2) \\
\end{array}$ & $\begin{array}{c}11,1 \\
(10,3-11,9) \\
\end{array}$ & $\begin{array}{c}15,2^{* 1} \\
(14,0-16,4) \\
\end{array}$ \\
\hline $\begin{array}{l}\text { Нейтрофилы } \\
\text { палочкоядерные,\% }\end{array}$ & $\begin{array}{c}7,8 \\
(6,6-9,0) \\
\end{array}$ & $\begin{array}{c}8,3 \\
(7,2-9,4) \\
\end{array}$ & $\begin{array}{c}9,2 \\
(7,8-10,6)\end{array}$ \\
\hline Эозинофилы, \% & 0 & $\begin{array}{c}0,4^{* 1} \\
(0,2-0,6) \\
\end{array}$ & $\begin{array}{c}0,6^{* 1} \\
(0,3-0,9) \\
\end{array}$ \\
\hline Базофилы, \% & $\begin{array}{c}1,0 \\
(0,9-1,1)\end{array}$ & $\begin{array}{c}0,5 \\
(0,2-0,8) \\
\end{array}$ & $\begin{array}{c}1,0 \\
(0,4-1,6) \\
\end{array}$ \\
\hline
\end{tabular}

Примечание: $n^{* 1,2,3}$ - достоверные различия относительно 1-й, 2-й и 3-й групп (p<0,05).

При гистологическом исследовании срезов селезенка незараженного паразитами омуля покрыта тонкой соединительнотканной капсулой. У здоровой особи омуля в возрасте пяти и шести лет капсула тонкая, ровная и составила в

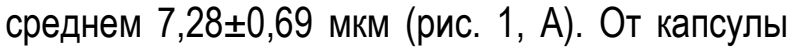
внутрь органа отходят перекладины - трабекулы, состоящие из рыхлой соединительной ткани, формирующей своеобразный «сетевидный каркас» селезенки. Наиболее массивные трабекулы - у ворот селезенки, в них расположены крупные кровеносные сосуды - трабекулярные артерии и вены, имеющие разную протяженность и конфигурацию. У половозрелых особей омуля толщина

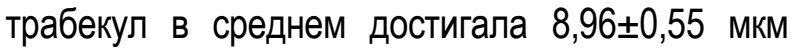
(табл. 2). Капсула и трабекулы состояли из плот- 
ной волокнистой соединительной и гладкой мышечной ткани с эластическими волокнами, позволяющими селезенке изменять свои размеры. В красной и белой пульпе отмечали значительное скопление пигментных пятен темно-бурого цвета. Фолликулы построены из лимфоидной ткани, образующей немногочисленные узелки овальной формы, которые рассредоточены по всей паренхиме селезенки (рис. 1).
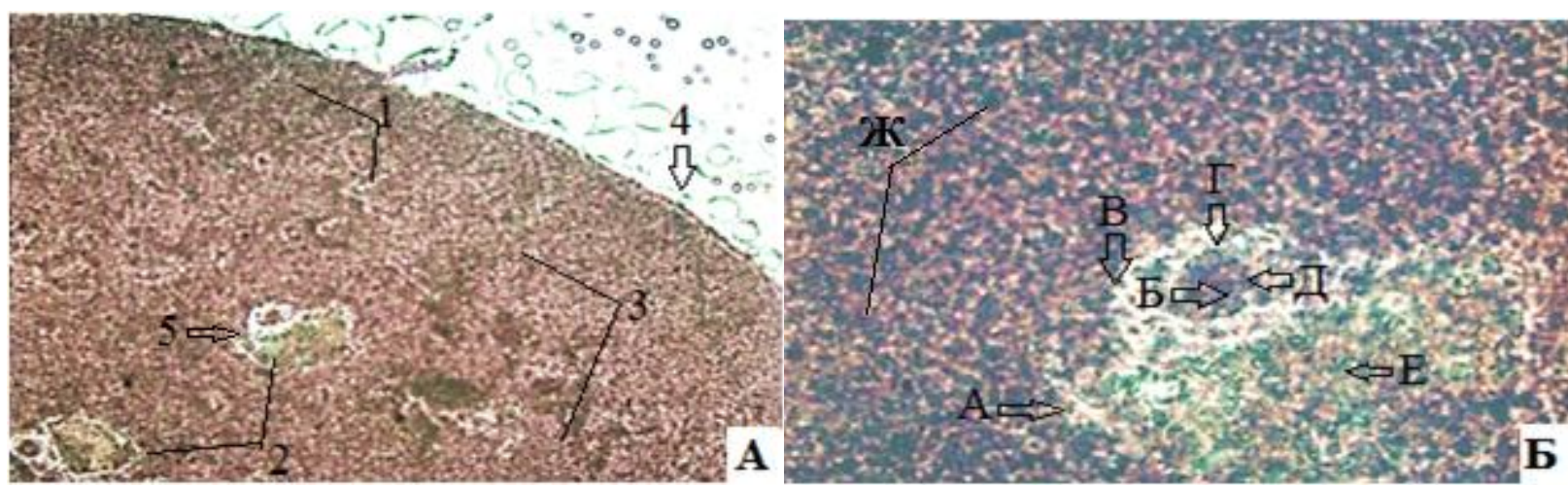

Puc.1. Микрофотографрия селезенки незараженного байкальского омуля: A - 1 - трабекуль в корковом веществе; 2 - белая пульпа в мозговом веществе; 3 - значительное скопление гемосидерина; 4 - капсула; 5 - венозный синус; 5 - а - венозный синус; 6 - центр размножения; в - маргинальная зона; г - периартериальная зона; $\partial$ - мантийная зона; е - центральная артерия; ж-макрофраги, клетки крови. Окраска гематоксилин и эозин (ув.об.10х10;10х40)

В развитом лимфатическом узелке различали несколько структурно-функциональных зон: периартериальную, светлый центр с мантийной зоной и маргинальную зону - место перехода белой пульпы в красную (рис. 1).

Светлый центр узелка по строению и функциональному назначению соответствует фолликулам лимфатического узла и является тимуснезависимым участком, в котором происходит дозревание В-лимфоцитов. Строение светлого участка отражает функциональное состояние лимфоузелка. Центр окружен плотным лимфоцитарным ободком - мантийной зоной (рис. 1, Б). Маргинальная зона является общей для Т- и Влимфоцитов. К ней прилегают краевые венозные синусы. Через эту зону в красную пульпу мигрируют плазмоциты. В фолликуле расположены центральные артерии, отчетливо граничащие с красной пульпой (рис. 1, Б). Диаметр белой пульпы составил в среднем 152,32 $\pm 11,29$ мкм. В красной пульпе, состоящей из ретикулярной ткани с находящимися в ней свободными клеточными элементами (клетками крови, плазматическими клетками и макрофрагами), наблюдали многочисленные кровеносные сосуды (рис. 1, А). Площадь белой пульпы здоровых животных варьировала от 13859,9 до 26751,2 мкм² и составила в среднем 17632,9 $\pm 1976,41$ мкм² (табл. 2).

Гистологические изменения наблюдали и на срезах селезенки омулей с низкой степенью инвазии. Отмечалось незначительное увеличение количества атрофичных, мелких фолликул. Клеточные структуры распределены неравномерно, они неоднородны. Значительное утолщение оболочек верхнего слоя, стертость и их неравномерное расположение, средняя толщина кап-

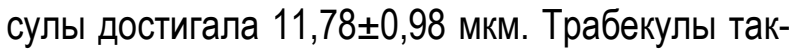
же расширены с явлениями отека и варьировали от 10,9 до 21,5 мкм и в среднем составили $16,10 \pm 2,28$ мкм (табл. 2). 


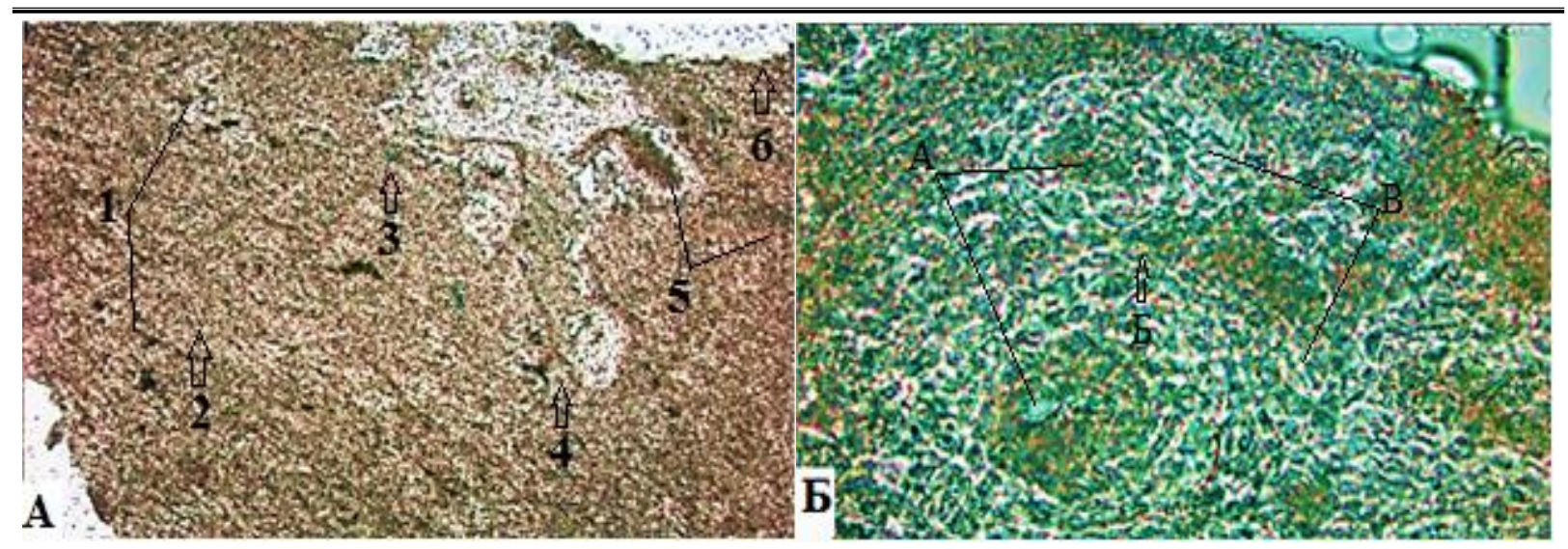

Puс. 2. Микроструктурные изменения селезенки омуля с низкой степенью инвазии с явлениями отека, расстройство микроциркулящии: венозное кровенаполнение, очаговые кровоизлияния: A 1 - скопление гемосидерина; 2 - кровеносные сосуды; 3 - расширение венозного синуса; 4 - центральная артерия; 5 - кровоизлияние в пульпе; 6 - бугристая капсула; 5 - a - расширение периартериальной зоны; б - центральная артерия; в - слияние фолликул с признаками дистрофии и гиперплазии. Окраска гематотоксилин и эозин (ув.об. 10х10; 10х40)

На большинстве срезов селезенки наблюдали расширение периартериальной зоны (Т-зоны). В результате расширения этой зоны стимулируется выработка больших Т-лимфоцитов. В маргинальной зоне отмечали увеличение количества малых Т- и В-лимфоцитов в результате перемещения Т-клеток с периартериальной зоны. Границы лимфатических фолликул селезенки стали нечеткими, отмечали небольшую отечность и мелкие очаговые кровоизлияния в пульпе (рис. 2, A). В зоне белой пульпы - признаки гиперплазии фолликул, местами фолликулы сливаются друг с другом. В фолликуле установили наличие незначительного количества округлых гиалиновых включений, диаметр фолликул составил в среднем 234,23 $\pm 20,31$ мкм (табл. 2). В паренхиме селезенки при слиянии фолликул наблюдали значительное увеличение размеров площади белой пульпы, в среднем площадь составила $31446,4 \pm 1175,38$ мкм² (рис. 2, Б). Красная пульпа с губчатой клеточностью была в состоянии дистрофии с меньшим содержанием пигментных пятен гемосидерина темно-бурого цвета. В сосудистом русле органа выявили расстройства микроциркуляции: просвет сосудов расширен, наблюдались очаговые кровоизлияния, стаз, венозное кровенаполнение (рис. 2, A).

Проведенные гистологические исследования селезенки омуля с высокой степенью инвазии подтвердили значительное развитие патологических процессов в отличие от таковых в группе со слабой степенью заражения. Наблюдали выраженный отек селезенки, стертый рисунок белой и красной пульп, расширение кровеносных сосудов в трабекулах и по всей плоскости среза, мелкоочаговые кровоизлияния (рис. 3). Поверхность селезенки относительно ровная, капсулы незначительно расширены и толщина в среднем составила 12,48 $\pm 0,28$ мкм. Стенка трабекул в состоянии отека расширена, с большим количеством кровенаполненных сосудов, толщина которых в среднем составила 11,57士0,68 мкм (рис. 3, А). На некоторых срезах селезенки рассматривали многочисленные элементы белой пульпы в виде нечетко определяющихся лимфоидных фолликул с угнетенными функциями, а в некоторых случаях с просветлением центра размножения Т-зоны и отсутствием границы маргинальной и мантийной зоны фолликул (рис. 3, Б). 

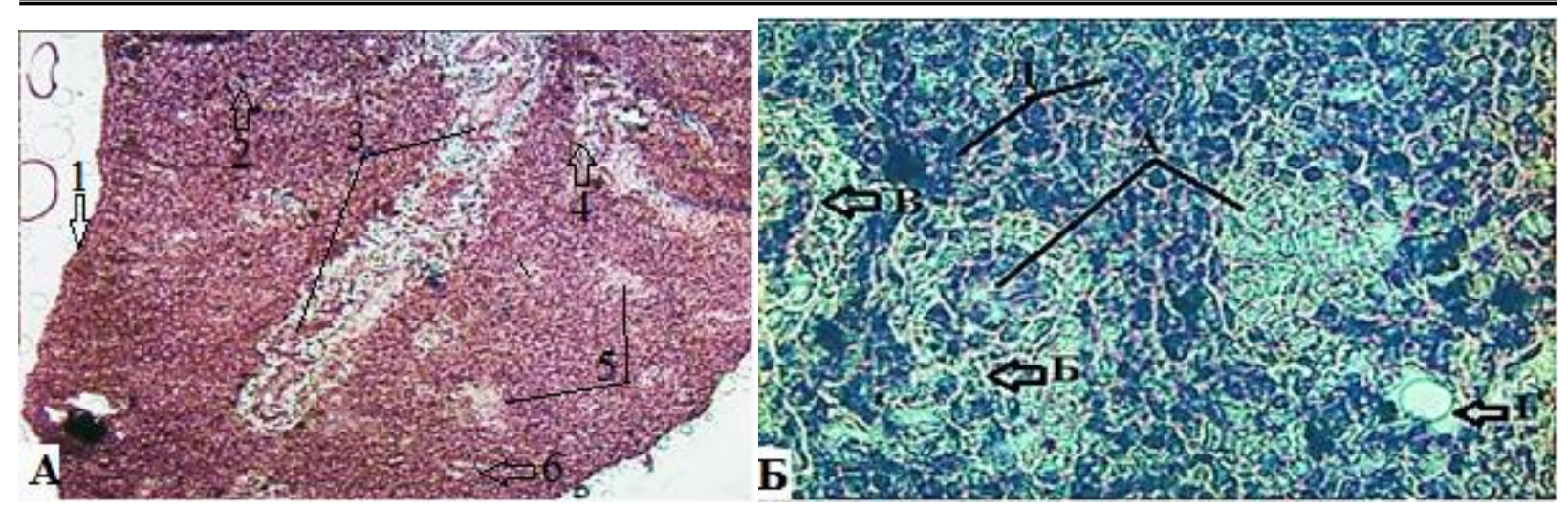

Puc. 3. Микроструктурные изменения селезенки омуля с высокой степенью инвазии: мозаичная структура с признаками хронического полнокровия сосудов, гиперплазии и атрофри центров размножения; $A$ - 1 - бугристая капсула; 2 - скопления гемосиредина; 3 - расширение трабекулярных артерий и вен; 4 - полиморфизм и гиперплазия белой пульпы; 5 - фолликулы с признаками атрофии; 6 - расширение венозных синусов; 5 - а - уменьшение площади лимфоодной ткани с просветлением зон размножения; б - гиалиновые включения; в - угнетение периартериальной зоны; г - центральная артерия; д - макрофаги, клетки крови. Окраска гематоксилин и эозин (ув.06.10x10; 10x40)

Маргинальная зона становится общей для Ти В-лимфоцитов (рис. 3, Б). Белая пульпа представлена полиморфными лимфатическими фолликулами с атрофичными центрами размножения. В просветленной зоне белой пульпы наблюдали расширение центральной артерии в ответ на интоксикацию секреторными продуктами плероцеркоида (рис. 3, Б). Размеры лимфатических фолликул оставались неизменными, наблюдали слабовыраженные округлые гиалиновые включения, и диаметр фолликул составил в среднем 163,88 $\pm 14,42$ мкм. При большом увеличении срезов наблюдали мозаичную структуру клеток паренхимы красной и белой пульпы с признаками дистрофии, гиперплазии и хронического полнокровия. В паренхиме красной пульпы отмечали большое количество клеток крови, плазматических клеток и макрофагов. Количество лимфоцитов снижено, сосуды относительно расширены. В красной пульпе отмечали редкие включения гемосидерина и увеличение площади белой пульпы в результате их слияния, площадь фолликул в среднем составила 33655,8 $\pm 1446,01$ мкм² (табл. 2).

Таблица 2

\section{Средние морфометрические данные структур селезенки омуля (n=17), $M \pm \mathrm{m}$}

\begin{tabular}{|c|c|c|c|}
\hline \multirow{3}{*}{ Структура селезенки } & \multirow{2}{*}{$\begin{array}{c}\text { Здоровые особи } \\
\text { незараженные }\end{array}$} & \multicolumn{2}{|c|}{ Степень заражения } \\
\hline & & $\begin{array}{c}\text { Низкая степень } \\
\text { инвазии }\end{array}$ & $\begin{array}{c}\text { Высокая степень } \\
\text { инвазии }\end{array}$ \\
\hline & 1-я группа & 2-я группа & 3-я группа \\
\hline Толщина капсулы, мкм & $7,28 \pm 0,69$ & $11,7 \pm 0,9^{* 1}$ & $12,4 \pm 0,28^{* 1}$ \\
\hline Ширина трабекул, мкм & $8,96 \pm 0,55$ & $16,1 \pm 2,2^{* 1}$ & $11,57 \pm 0,68$ \\
\hline Диаметр белой пульпы, мкм & $151,32 \pm 11,29$ & $234,2 \pm 20,3^{* 1,3}$ & $163,8 \pm 14,42^{*} 2$ \\
\hline Площадь белой пульпы, мкм² & $17632,9 \pm 1976,4$ & $31446,4 \pm 1175,3^{* 1}$ & $32155,0 \pm 1927,6^{* 1}$ \\
\hline
\end{tabular}

* - отклонение статистически значимо по отношению к норме, между 2-й и 3-й группами, Р $\leq 0,05$. 
В данной работе комплекс гематологических показателей системы кроветворения с гистологическим микроанализом позволил выявить структурные изменения селезенки у особей байкальского омуля при разной степени инвазии.

Анализ состава крови байкальского омуля, зараженного плероцеркоидами D. dendriticum, по сравнению с незараженными особями свидетельствует о нарушении процессов пролиферации и дифференцировки клеточных элементов. И значительное повышение уровня нейтрофилов и моноцитов указывает на усиление защитной реакции организма омуля на токсины гельминтов (см. табл. 1). В связи с этим структурные изменения в морфоофункциональных зонах селезенки омуля являются важными дополнительными факторами при оценке иммунологических реакций при заражении цестодами.

По данным О.Е. Мазур и др. (2013), изменения красной крови у зараженных плероцеркоидами D. dendriticum животных однотипные: достоверно снижается уровень гемоглобина и общее число эритроцитов. В динамике уровня иммуноцитов крови облигатных и необлигатных хозяев в период активного созревания плероцеркоидов прослеживается единая тенденция снижение общего числа лейкоцитов, абсолютного содержания Т-лимфоцитов и их субполяций Т-хелперов и Т-цитоксических клеток [18].

Аналогичные результаты получены А.С. Фоминой, С.В. Прониной (2015). Выявлено, что заражение рыб лентецом чаечным D. dendriticum приводило к значительному снижению площади и числа макросрагальных центров в селезенке и свидетельствовало об угнетении моноцитарно-макрофрагального звена иммунной защиты рыб [19].

Микроморфология органов иммунной системы рыб при инвазии гельминтами остается практически малоизученной, имеющаяся в литературе информация отрывочна и недостаточна. Отсутствует анализ, дающий целостную картину развития иммунитета рыб при дифиллоботриозах.

\section{Выводы}

В результате анализа полученных гематологических, гистологических и морфометрических показателей структуры селезенки байкальского омуля установили:

1. При низкой степени заражения стенки пищеварительного тракта омуля D. dendriticum в структуре селезенки отмечались губчатая клеточность красной пульпы, делимфотизация фолликул с мелкими очаговыми кровоизлияниями. В ответ на воздействие секреции гельминта происходило расширение периартериальной зоны (Т-зоны). В маргинальной зоне отмечали увеличение количества малых Т- и Влимфоцитов.

2. При высокой степени инвазии в структуре селезенки омулей отмечали выраженные патологические изменения: мозаичный рисунок, признаки дистрофии, гиперплазии и хронического полнокровия. С усилением инвазии отмечалось угнетение активности выработки Т-лимфоцитов в периартериальной зоне селезенки. В ответ на усиление интоксикации секреторными продуктами плероцеркоидов наблюдалось расширение центральной артерии, необходимое для восстановления равновесия внутренней среды кровеносной системы.

\section{Литература}

1. FAO. The state of world fisheries and aguaculture (SOFIA) 2006. Rome: FAO Fisheries and Aguaculture Department, 2007.

2. Clifton-Hadley R.S. Economic importance of proliferative kidney disease of salmonid fish in England and Wales / R.S. Clifton-Hadley, D. Bucke, R.H. Richards // Vet. Rec. 1986. V. 20. P. 305-306.

3. Moran J.D.W. A. review of the myxosporean genus KudoaMeglitsh, 1947, and its impact on the international aguculture industry and commercial fisheries // Aguaculture. 1999. V. 172. P.163-196.

4. Johnson S.C. A review of the impactof parasitic copepods on marine aguaculture / S.C. Johnson, J.W.Treasurer, S. Bravo [et al.] // Zool. Stud. V. 43. P. 229-243.

5. Krkosek M. Epizootics of wild fish induced by farm fish / M. Krkosek M.A. Lewis, A. Morton [et al.] // Proc. Natl. Acad. SCl. USA. 2006. V. 103. P. 15506-15510.

6. Пронин Н.М. Паразиты рыб и других гидробионтов Байкальского региона, опасные для 
людей // Проблемы общей и региональной паразитологии. Улан-Удэ: Изд-во Бурят. с.-х. академии, 2000. С. 38-43.

7. Беляев Е.Н., Ясинский А.А., Сыскова Т.Г. [и др.]. Заболеваемость протозоозами и гельминтозами населения Российской Федерации в 1996-2000 гг.: информ. сб. стат. и аналит. мат-лов. М.: Федер. центр Госсанэпиднадзора Минздрава России, 2001.112 с.

8. Верещагин А.И. Заболеваемость протозоозами и гельминтозами в Российской Федерации за 2012-2013 гг.: инфоорм. сб. стат. и аналит. мат-лов. М.: Федер. центр Госсанэпиднадзора Минздрава России, 2014. 79 с.

9. Шабунов А.А., Радченко Н.М. Паразиты рыб, земноводных и чайковых птиц в экосистеме крупных водоемов Вологодской области: монография. Вологда: ВоГТУ, 2012. 243 с.

10. Cox. F.E.G. Designer vaccines for parasitic diseases // int. J. Parasitiol. 1997. V. 27. P. 1147-1157.

11. Пронин Н.М. Экология паразитов гидробионтов бассейна озера Байкал и структура паразитарных систем: дис. ... д-ра биол. наук. Улан-Удэ, 2004. 74 с.

12. Коромыслов Г.Ф. Ускорить обновление // Ветеринария. 1988. № 10. С. 3-6.

13. Федоров Ю.Н. Ветеринарная биотехнология: состояние и перспективы // Ветеринария. 1990. № 2. С. 3-6.

14. Ткачева В.Г., Рьжков Л.П. Реакция печени радужной форели (Salmoirideus G.) на антропогенное загрязнение // Тез. докл. 1-й конгр. ихтиологов России (Астрахань, сент. 1997). Астрахань, 1997.

15. Федорова Н.Н., Крючков В.И., Зайцев В.Ф. Морфологическая характеристика печени рыб в современных экологических условиях // Российские морфологические ведомости. 1999. № 3-4 C. 174-180.

16. Dupoy-Camet J., Year H. Diphyllobothrium // Molecular detection of foodborne pathogens, London, New York: Taylor and Francis. 2010. P. 781-788.

17. Грищенко Л.И., Акбаев М.Ш., Васильков Г.В. Болезни рыб и основы рыбоводства. М.: Колос, 1999. $456 \mathrm{c}$.

18. Мазур О.Е, Пронин Н.М., Фомина А.C. [и др.]. Сравнительный анализ гематологических, морфологических и иммунологиче- ских реакций облигатных и необлигатных хозяев лентеца D. dendriticum (CESTODA: PSEUDOPHYLLIDEA) // Российский паразитологический журнал. 2013. Вып.1. С. 54-60.

19. Фомина А.С., Пронина С.В. Морфофункциональные характеристики селезенки байкальского омуля при заражении цестодой Ddentriricum (PSEUDOPHYLLIDEA Diphyllob thripidae) // Вестник рыбохозяйственной науки. 2015. Т. 2 №1 (5). С. 52-57.

\section{Literatura}

1. FAO. The state of world fisheries and aguaculture (SOFIA) 2006. Rome: FAO Fisheries and Aguaculture Department, 2007.

2. Slifton-Hadley R.S. Economic importance of proliferative kidney disease of salmonid fish in England and Wales I R.S. Clifton-Hadley, D. Bucke, R.H. Richards // Vet. Rec. 1986. V. 20. P. 305-306.

3. Moran J.D.W. A. review of the myxosporean genus Kudoa Meglitsh, 1947, and its impact on the international aguculture industry and commercial fisheries // Aguaculture. 1999. V. 172. P.163-196.

4. Johnson S. C. A review of the impactof parasitic copepods on marine aguaculture I SCJohnson, J.W. Treasurer, S. Bravo [et al.] /I Zool. Stud. V. 43. P. 229-243.

5. Krkosek M. Epizootics of wild fish induced by farm fish / M. Krkosek M.A. Lewis, A. Morton [et al.] // Proc. Natl. Acad. SCI. USA. 2006. V. 103. P. $15506-15510$.

6. Pronin N.M. Parazity ryb i drugih gidrobiontov Bajkal'skogo regiona, opasnye dlja ljudej // Problemy obshhej i regional'noj parazitologii. Ulan-Udje: Izd-vo Burjat. s.-h. akademii, 2000. S. 38-43.

7. Beljaev E.N., Jasinskij A.A., Syskova T.G. [i dr.]. Zabolevaemost' protozoozami i gel'mintozami naselenija Rossijskoj Federacii v 1996-2000 gg.: inform. sb. stat. i analit. matlov. M.: Feder. centr Gossanjepidnadzora Minzdrava Rossii, 2001.112 s.

8. Vereshhagin A.l. Zabolevaemost' protozoozami i gel'mintozami v Rossijskoj Federacii za 2012-2013 gg.: inform. sb. stat. i analit. mat-lov. M.: Feder. centr Gossanepidnadzora Minzdrava Rossii, 2014. 79 s. 
9. Shabunov A.A., Radchenko N.M. Parazity ryb, zemnovodnyh i chajkovyh ptic $v$ jekosisteme krupnyh vodoemov Vologodskoj oblasti: monografija. Vologda: VoGTU, 2012. $243 \mathrm{~s}$.

10. Cox. F.E.G. Designer vaccines for parasitic diseases // int. J. Parasitiol. 1997. V. 27. P. 1147-1157.

11. Pronin N.M. Jekologija parazitov gidrobiontov bassejna ozera Bajkal i struktura parazitarnyh sistem: dis. ... d-ra biol. nauk. Ulan-Udje, 2004.74 s.

12. Koromyslov G.F. Uskorit' obnovlenie /I Veterinarija. 1988. № 10. S. 3-6.

13. Fedorov Ju.N. Veterinarnaja biotehnologija: sostojanie i perspektivy // Veterinarija. 1990. № 2. S. 3-6.

14. Tkacheva V.G., Ryzhkov L.P. Reakcija pecheni raduzhnoj foreli (Salmoirideus G.) na antropogennoe zagrjaznenie // Tez. dokl. 1-j kongr. intiologov Rossii (Astrahan', sent. 1997). Astrahan', 1997.

15. Fedorova N.N., Krjuchkov V.I., Zajcev V.F. Morfologicheskaja harakteristika pecheni ryb v sovremennyh jekologicheskih uslovijah // Rossijskie morfologicheskie vedomosti. 1999. № 3-4 S. 174-180.

16. Dupoy-Camet J., Year H. Diphyllobothrium /I Molecular detection of foodborne pathogens, London, New York: Taylor and Francis. 2010. P. 781-788.

17. Grishhenko L.I., Akbaev M.Sh., Vasil'kov G.V. Bolezni ryb i osnovy rybovodstva. M.: Kolos, 1999. $456 \mathrm{~s}$.

18. Mazur O.E, Pronin N.M., Fomina A.S. [i dr.]. Sravnitel'nyj analiz gematologicheskih, morfologicheskih i immunologicheskih reakcij obligatnyh i neobligatnyh hozjaev lenteca $D$. dendriticum (SECTODA: PSEUDOPHYLLIDEA) // Rossijskij parazitologicheskij zhurnal. 2013. Vyp.1. S. 54-60.

19. Fomina A.S., Pronina S.V. Morfofunkcional'nye harakteristiki selezenki bajkal'skogo omulja pri zarazhenii cestodoj Ddentriricum (PSEUDOPHYLLIEA Diphyllobthriidae) // Vestnik rybohozjajstvennoj nauki. 2015. T. 2 №1 (5). S. 52-57. 